\title{
Iron speciation in aerosol dust influences iron bioavailability over glacial-interglacial timescales
}

\author{
A. Spolaor, ${ }^{1,2}$ P. Vallelonga, ${ }^{2,3}$ G. Cozzi, ${ }^{2}$ J. Gabrieli, ${ }^{2}$ C. Varin, ${ }^{4}$ N. Kehrwald, ${ }^{4}$ \\ P. Zennaro, ${ }^{4}$ C. Boutron, ${ }^{5}$ and C. Barbante ${ }^{2,4}$ \\ Received 2 February 2013; accepted 25 February 2013; published 27 April 2013.
}

[1] Iron deposition influences primary production and oceanic sequestration of atmospheric carbon dioxide $\left(\mathrm{CO}_{2}\right)$. Iron has two oxidation states, $\mathrm{Fe}(\mathrm{II})$ and $\mathrm{Fe}(\mathrm{III})$, with $\mathrm{Fe}(\mathrm{II})$ being more soluble and available for oceanic phytoplankton uptake. The past proportions of soluble iron in aerosol dust remain unknown. Here we present iron speciation $\left(\mathrm{Fe}^{2+}\right.$ and $\left.\mathrm{Fe}^{3+}\right)$ in the Antarctic Talos Dome ice core over millennial time scales. We demonstrate that iron speciation over the last $55 \mathrm{kyr}$ is linked to increasing quantities of fine dust (FD) $(0.7-5 \mu \mathrm{m})$ and intensified long-range dust transport. We propose that $\mathrm{Fe}(\mathrm{II})$ and $\mathrm{Fe}^{2+}$ production is principally enhanced in FD by photoreduction, although $\mathrm{pH}$ and organic complexation may also contribute to the speciation dynamics. During the Last Glacial Maximum, $\mathrm{Fe}^{2+}$ concentrations in dust increased by up to seven times more than interglacial levels, while $\mathrm{Fe}^{3+}$ only doubled. Cold and dusty climatic periods may increase the percentage of biologically available $\mathrm{Fe}(\mathrm{II})$ and $\mathrm{Fe}^{2+}$ deposited in the nutrient-limited Southern Ocean, allowing greater phytoplankton uptake and perhaps increased $\mathrm{CO}_{2}$ drawdown. Citation: Spolaor, A., P. Vallelonga, G. Cozzi, J. Gabrieli, C. Varin, N. Kehrwald, P. Zennaro, C. Boutron, and C. Barbante (2013), Iron speciation in aerosol dust influences iron bioavailability over glacial-interglacial timescales, Geophys. Res. Lett., 40, 1618-1623, doi:10.1002/grl.50296.

\section{Introduction}

[2] Iron plays an important role in oceanic biogeochemistry [Jickells et al., 2005] due to its ability to limit the biomass of phytoplankton populations in large oceanic zones [Martin and Fitzwater, 1988] and consequent atmospheric carbon dioxide $\left(\mathrm{CO}_{2}\right)$ drawdown [Joos et al., 1991]. The artificial addition of iron to equatorial Pacific Ocean waters (IronEx) [Coale, 1998] and the polar Southern Ocean (SOIREE) [de Baar et al., 2005] resulted in significant increases in phytoplankton productivity and abundance.

\footnotetext{
${ }^{1}$ Department of Earth Science, University of Siena, Siena, Italy.

${ }^{2}$ Institute for the Dynamics of Environmental Processes - CNR, University of Venice, Venice, Italy.

${ }^{3}$ Centre for Ice and Climate, Niels Bohr Institute, Copenhagen, Denmark.

${ }^{4}$ Department of Environmental Sciences, Informatics, and Statistics, University Ca'Foscari of Venice, Venice, Italy.

${ }^{5}$ Laboratoire de Glaciologie et Géophysique de l'Environnement (UMR UJF/CNRS 5183), Domaine Universitaire, Saint Martin d'Hères, France.

Corresponding author: C. Barbante, Institute for the Dynamics of Environmental Processes - CNR, University of Venice, Dorsoduro 2137, IT-30123 Venice, Italy. (barbante@unive.it)

(C)2013. American Geophysical Union. All Rights Reserved. 0094-8276/13/10.1002/grl.50296
}

Recent ocean fertilization experiments confirm that phytoplankton blooms caused by iron addition draw down considerable $\mathrm{CO}_{2}$ [Smetacek et al., 2012]. However, uncertainty remains regarding the net consequence of this biological pump on the atmospheric system [Fischer et al., 2010] and the extent to which iron controls this mechanism [Sunda, 2010] over glacial-interglacial cycles.

[3] Ice cores are an accurate archive of late Pleistocene climate, allowing detailed reconstructions of atmospheric composition and aerosol loading, which are important factors for understanding climate dynamics [Wolff et al., 2006]. Changes in the concentrations of many elements, including iron, have been studied in Antarctic sites, such as Dome C $\left(75^{\circ} 06^{\prime} \mathrm{S}, 123^{\circ} 24^{\prime} \mathrm{E} ; 3234 \mathrm{MASL}\right)$ [Wolff et al., 2010] and Vostok ( $78^{\circ} 27^{\prime} \mathrm{S}, 106^{\circ} 50^{\prime} \mathrm{E} ; 3488$ MASL) [Gabrielli et al., 2005]. Iron speciation presents additional analytical challenges, and this is the first study to quantify iron species in any ice core. We determined iron speciation $\left(\mathrm{Fe}^{2+}\right.$ and $\left.\mathrm{Fe}^{3+}\right)$ in Talos Dome (TD) $\left(159^{\circ} 04^{\prime} 21^{\prime \prime} \mathrm{E}, 72^{\circ} 47^{\prime} 14^{\prime \prime} \mathrm{S}\right.$; 2315 MASL) ice core samples using flow injection analysis coupled with collision/reaction cell inductively coupled plasma mass spectrometry (FIA-CRC-ICP-MS) [Spolaor et al., 2012] to provide the first evaluation of iron speciation between glacial and interglacial climates with implications for carbon sequestration over millennial time scales.

[4] The biogeochemical properties of iron are strongly influenced by speciation [Trapp et al., 2010], with Fe(II) species being more soluble and bioavailable [Shaked et al., 2005] than Fe(III) [Baker and Croot, 2010]. Organic complexation may also strongly affect the solubility of iron [Rue and Bruland, 1995] and the oxidation rate of $\mathrm{Fe}(\mathrm{II})$. Marine algae more readily take up soluble iron, yet the fraction of soluble iron present in aerosol dust is still unknown [Aguilar-Islas et al., 2010; Baker and Jickells, 2006; Chever et al., 2010]. Observations demonstrate that dust origin influences the soluble iron fraction, with dust particles from arid desert soils presenting lower solubility compared to glacially weathered soils [Schroth et al., 2009]. Baker and Jickells [2006] proposed that iron solubility is not fixed and changes predictably as an inverse function of dust concentration on both spatial and temporal scales, while Zhuang et al. [1992b] reported a change in iron speciation due to atmospheric travel time, with an increase in $\mathrm{Fe}$ (II) and solubility associated with remote sources. Longrange atmospheric transport strongly influences iron speciation, enriches $\mathrm{Fe}$ (II) by $50 \%-100 \%$ with respect to total source iron, and increases solubility by a factor of 5-17 [Zhuang et al., 1992b]. Variations in Antarctic iron concentrations are strongly linked to dust deposition and transport [Delmonte et al., 2010], where large-size particles $(5-20 \mu \mathrm{m})$ are predominant during interglacials, while fine dust (FD) $(0.7-5 \mu \mathrm{m})$ 
particles become predominant during glacials, indicating changes in the dust provenance and the travel time [Delmonte et al., 2010]. Although the net effect of glacial dust flux changes on oceanic primary productivity is still unclear [Wolff et al., 2006], syntheses conclude that this mechanism may account for 20 to 40 ppmv of the 80-100 ppmv $\mathrm{CO}_{2}$ changes observed over glacial-interglacial transitions [Fischer et al., 2010].

\section{Methods}

[5] Ice core samples were collected in 2005-2007 at TD. The site is an ice dome at the junction between the East Antarctic Plateau and the Transantarctic Mountains, located approximately $290 \mathrm{~km}$ from the Southern Ocean. The mean temperature is $-41^{\circ} \mathrm{C}$ and snow accumulation is $80 \mathrm{~mm}$ we $\mathrm{yr}^{-1}$ [Frezzotti et al., 2004]. The ice sections were transported in a frozen state to the University of Venice and cut into $2 \times 3 \times 3 \mathrm{~cm}$ pieces using a modified commercial band saw and decontaminated using a rinsing technique [Ruth et al., 2008]. Iron speciation was determined by FIA-CRC-ICP-MS as described in detail by Spolaor et al. [2012]. This method enables the determination of leachable $\mathrm{Fe}^{2+}$ and $\mathrm{Fe}^{3+}$ in ice core samples using a NiNTA Superflow chelating system to separate the Fe species. At $\mathrm{pH} 2$, the resin completely retains $\mathrm{Fe}^{3+}$ with no retention of $\mathrm{Fe}^{2+}$. After isolating and determining $\mathrm{Fe}^{3+}$, we oxidized the $\mathrm{Fe}^{2+}$ using $\mathrm{H}_{2} \mathrm{O}_{2}$ and determined the $\mathrm{Fe}^{2+}$ concentration as the difference between the two measurements. The samples were kept frozen at $-20^{\circ} \mathrm{C}$ until immediately prior to analysis due to the rapid oxidation of $\mathrm{Fe}^{2+}$ to $\mathrm{Fe}^{3+}$ in liquid samples.

[6] Dissolvable $\mathrm{Fe}$ concentrations were determined in discrete samples of TD ice sampled for continuous flow analysis [Vallelonga et al.., 2013]. For each $1 \mathrm{~m}$ long ice sample, $15 \mathrm{~mL}$ was collected in Coulter Counter accuvettes at a rate of $0.5 \mathrm{~mL} / \mathrm{min}$. The sample preparation and analytical methods have been previously reported [Barbante et al., 1999]. Melted samples were acidified to $\mathrm{pH} 1$ using subboiled distilled $\mathrm{HNO}_{3}$ (Romil, Cambridge, UK) and analyzed at least $24 \mathrm{~h}$ later by sector field ICP-MS (Finnigan ${ }^{\mathrm{TM}}$ ELEMENT2, Thermo Fisher Scientific Inc., Bremen, Germany) coupled to an APEX Q desolvating introduction unit (Elemental Scientific, Omaha, Nebraska, USA). The detection limit, defined as three times the standard deviation of the instrument blank, was $0.029 \mathrm{ng} \mathrm{g}^{-1}$, with precisions of $16 \%$ for Holocene samples and $10 \%$ for Last Glacial Maximum (LGM) samples. We use the methods published by Gaspari et al. [2006] to report acid-leachable Fe concentrations, although it has been demonstrated that 1 month is required to completely dissolve Fe-bearing aerosol particles [Edwards et al., 2006]. The time period integrated by each sample varies from approximately $15 \mathrm{yr}$ at $0.6 \mathrm{kyr}$ before present (BP; $1950 \mathrm{CE})$ to $150 \mathrm{yr}$ at $55 \mathrm{kyr} \mathrm{BP}$. We compare our data to dust concentrations and particle size distributions in parallel sample aliquots [Delmonte et al., 2010].

[7] We employed statistical analyses to test the strength of the association between Fe species, dust concentrations, and size fractions (both fine and coarse) and sodium concentrations (a proxy for marine air mass inputs). A logarithmic transformation of all variables is necessary to account for the skewed distributions of the observed values. The association between iron species and the proxies was evaluated by linear regression. A residual analysis checked that the statistical assumptions for linear regression inference were satisfied. The strongest predictor of $\log \left(\mathrm{Fe}^{2+}\right)$ is the logarithm of FD $(\mathrm{t}=3.970, \mathrm{p}<0.001)$, followed by the logarithm of sodium $(\mathrm{t}=2.488, \mathrm{p}=0.018)$ and the logarithm of coarse dust $(\mathrm{CD})(\mathrm{t}=2.114, \mathrm{p}=0.042)$. For $\log \left(\mathrm{Fe}^{3+}\right)$, the strongest predictor is the logarithm of $F D(t=3.181$, $\mathrm{p}=0.003)$ and to a lesser extent the log-sodium $(\mathrm{t}=2.086$, $\mathrm{p}=0.044)$. CD is weakly associated with this iron species $(t=1.929, p=0.063)$. The linkage between $\log \left(\mathrm{Fe}^{2+}\right)$ and sodium is likely due to the similar trend of both elements during the glacial. Despite the correlation, it is well demonstrated that dust is the main source of iron in Antarctica [Wolff et al., 2006], while the southern ocean is also influenced by other iron sources, including icebergs, subglacial meltwater and upwelling water masses [Raiswell and Canfield, 2012]. For Antarctic ice, sodium is widely used as a proxy for marine salt influxes. The ratio of total iron content to total FD load is shown in Figure 2, as is a smoothing spline reconstruction. We observe that there is little change in the ratio of iron to dust at TD, particularly over

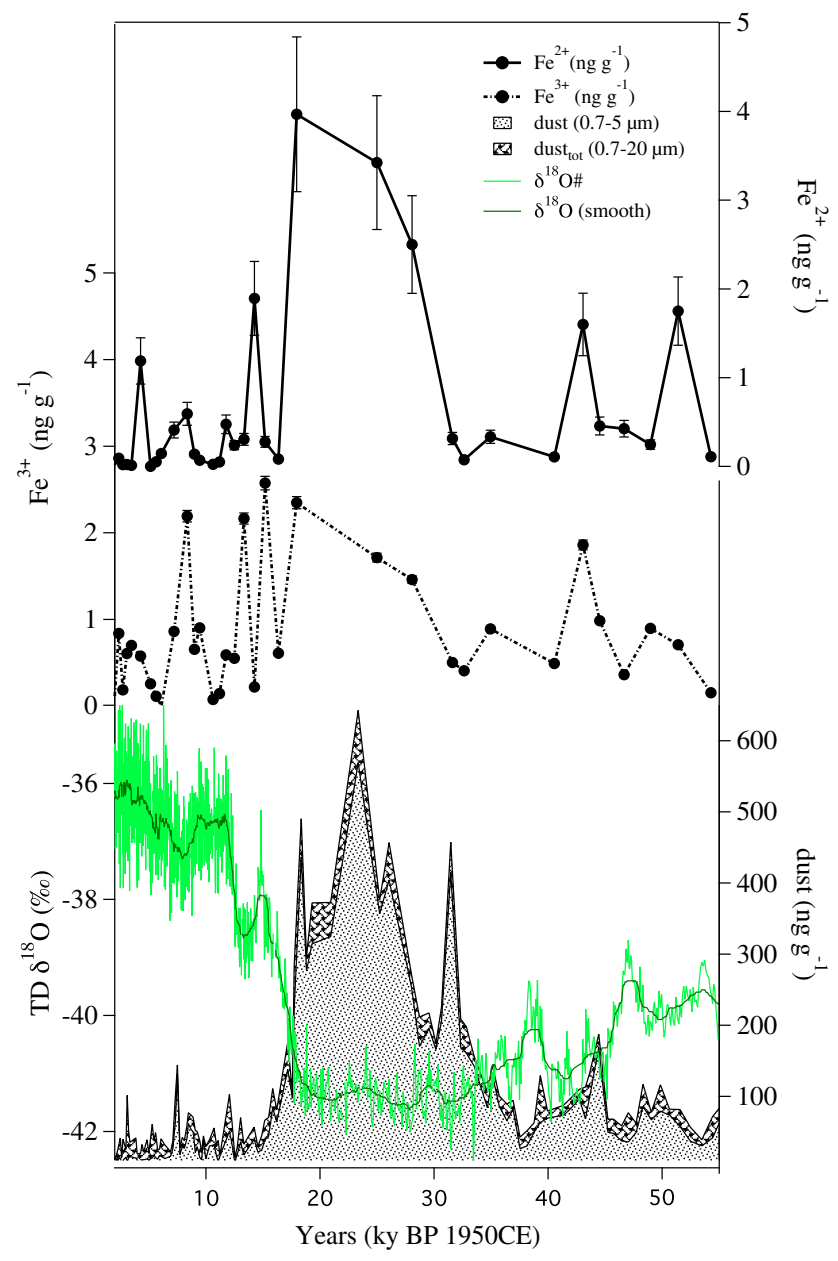

Figure 1. $\mathrm{Fe}^{2+}$ (black line) and $\mathrm{Fe}^{3+}$ (dotted line) concentrations $\left(\mathrm{ng} \mathrm{g}^{-1}\right)$ in TD ice core samples. The light-shaded field represents FD $(0.7-5 \mu \mathrm{m})$ concentrations (FP) [Delmonte et al., 2010], while the dark-shaded field shows total $(0.7-20 \mu \mathrm{m})$ dust concentrations. The light and dark green lines respectively indicate raw and smoothed variations in $\delta^{18} \mathrm{O}$, a paleotemperature proxy [Stenni et al., 2011]. 
Table 1. Summary of Average Fe and Dust Concentrations $\left(\mathrm{ng} \mathrm{g}^{-1}\right)$ in TD Ice ${ }^{1}$

\begin{tabular}{lllllll}
\hline Age (kyr) & \multicolumn{1}{c}{$\mathrm{Fe}^{2+}$} & \multicolumn{1}{c}{$\mathrm{Fe}^{3+}$} & $\mathrm{Fe}^{2+} / \mathrm{Fe}^{3+}$ & $\mathrm{Fe}_{\text {tot }}$ & Dust $(0.7-5 \mu \mathrm{m})$ & Dust $(5-20 \mu \mathrm{m})$ \\
\hline 1-14(Holocene) & $0.21(1)$ & $0.59(1)$ & $0.43(1)$ & $1.34(1)$ & $21.1(1)$ & $19.2(1)$ \\
14-32(LGM) & $1.57(7.5)$ & $1.23(2.1)$ & $1.88(4.4)$ & $8.79(6.6)$ & $211.4(10.0)$ & $31.6(1.6)$ \\
32-55(MIS 3) & $0.63(3.0)$ & $0.79(1.3)$ & $0.82(1.9)$ & $1.35(1)$ & $76.5(3.6)$ & $22.7(1.2)$ \\
\hline
\end{tabular}

${ }^{1} \mathrm{The}^{2+} \mathrm{Fe}^{2+} / \mathrm{Fe}^{3+}$ mass ratio is also shown for the corresponding time periods. Enrichments beyond average Holocene values are shown in parentheses. LGM signifies Last Glacial Maximum and MIS 3 represents Marine Isotope Stage 3.

glacial-interglacial time scales, indicative of a constant dustderived source of iron. Slightly enhanced and more variable iron/dust ratios can be observed during the most recent Holocene samples, which have been attributed to the deglacial activation of dust deflation zones local to TD [Delmonte et al., 2010].

\section{Results and Discussion}

[8] Our results demonstrate a difference in iron speciation from glacial to interglacial climates, with $\mathrm{Fe}^{3+}$ concentrations being greater than $\mathrm{Fe}^{2+}$ concentrations during the interglacial and the opposite occurring during the glacial (Figure 1). During the present interglacial (1-14 kyr before $1950 \mathrm{AD}$; hereinafter referred to as $\mathrm{BP}), \mathrm{Fe}^{3+}$ concentrations were between 0.02 and $2.19 \mathrm{ng} \mathrm{g}^{-1}$ with an average concentration of $0.59 \mathrm{ng} \mathrm{g}^{-1}$. $\mathrm{Fe}^{2+}$ concentrations ranged from below detection limits of 0.01 to $1.89 \mathrm{ng} \mathrm{g}^{-1}$ with an average of $0.21 \mathrm{ng} \mathrm{g}^{-1}$ (Table 1). Holocene dust deposition at TD is characterized by a similar abundance of CD particles $(5-20 \mu \mathrm{m})$ and FD particles $(0.7-5 \mu \mathrm{m})$. CD has a mean concentration of $19.2 \mathrm{ng} \mathrm{g}^{-1}$, while FD has $21.1 \mathrm{ng} \mathrm{g}^{-1}$. CD is attributable to short-distance dust transport from local high-altitude icefree areas of Victoria Land, while FD is attributable to distant emission sources, predominantly Southern South America [Delmonte et al., 2010]. In the last glacial period, evaluated here between 14 and 55 kyr BP, aerosol dust loading increased with particle size distributions shifting toward finer fractions $(0.7-5 \mu \mathrm{m})$. During the LGM (14-32 kyr BP), the coarse particle percentage was usually less than $20 \%$ of the total dust mass [Delmonte et al., 2010], with the increased fluxes of fine aerosols attributed to long-range transport from deflation sources in Patagonia. The greater concentrations of glacial dust (up to $640 \mathrm{ng} \mathrm{g}^{-1}$ during the LGM) increased the fluxes of many elements to the Antarctic region [Wolff et al., 2010], including $\mathrm{Fe}^{2+}$ and $\mathrm{Fe}^{3+}$. $\mathrm{Fe}^{2+}$ concentrations increased by seven-fold during the LGM, from interglacial values of 0.21 to $1.57 \mathrm{ng} \mathrm{g}^{-1}$. We also observed an increase in $\mathrm{Fe}^{3+}$ concentration, with LGM values $\left(1.23 \mathrm{ng} \mathrm{g}^{-1}\right)$ approximately double those of the interglacial $\left(0.59 \mathrm{ng} \mathrm{g}^{-1}\right)$. The earlier glacial period of marine isotope stage (MIS) 3, evaluated between 32 and $55 \mathrm{kyr}$ BP, was characterized by lower fine particle concentrations $\left(76.5 \mathrm{ng} \mathrm{g}^{-1}\right)$, although still higher than interglacial values $\left(19.2 \mathrm{ng} \mathrm{g}^{-1}\right)$, with greater inputs of CD particles. During MIS $3, \mathrm{Fe}^{2+}$ concentrations $\left(0.63 \mathrm{ng} \mathrm{g}^{-1}\right)$ were three times greater than interglacial values, while $\mathrm{Fe}^{3+}$ concentrations were similar to interglacial values $\left(0.79 \mathrm{ng} \mathrm{g}^{-1}\right)$ (Figure 1).

[9] The association of iron speciation ratios $\left(\mathrm{Fe}^{2+} / \mathrm{Fe}^{3+}\right)$ with the presence of FD and CD fractions was tested. After the variables were log-transformed due to their skewed distribution, the results suggest that iron speciation is weakly associated with $\mathrm{FD}(\mathrm{t}=2.028, \mathrm{p}=0.051)$ and not associated with CD $(\mathrm{t}=1.081, \mathrm{p}=0.2879)$. These results are interpreted cautiously given the small sample size. Low $\mathrm{Fe}^{2+} / \mathrm{Fe}^{3+}$ values were determined for the interglacial (average $=0.4$, range $=0.02-2.1)$ and higher values for the LGM (average $=1.9$, range $=0.10-8.6$ ) and MIS 3 (average $=0.82$, range $=0.21-2.47$ ) (Figure 2). The LGM average was not greatly influenced by one sample (14 kyr BP) with an $\mathrm{Fe}^{2+} / \mathrm{Fe}^{3+}$ value of 8.6 because removing this sample changes the LGM average to 0.92 , which remains substantially greater than the interglacial average.

[10] The enhancement of Fe(II) species in TD ice can be linked to the LGM period when dust fluxes were highest and the FD proportion was greatest. Antarctic glacial dust has been isotopically linked to deflation sources in southern South America [Delmonte et al., 2010]. We propose that the changing glacial-interglacial Fe speciation in Antarctica

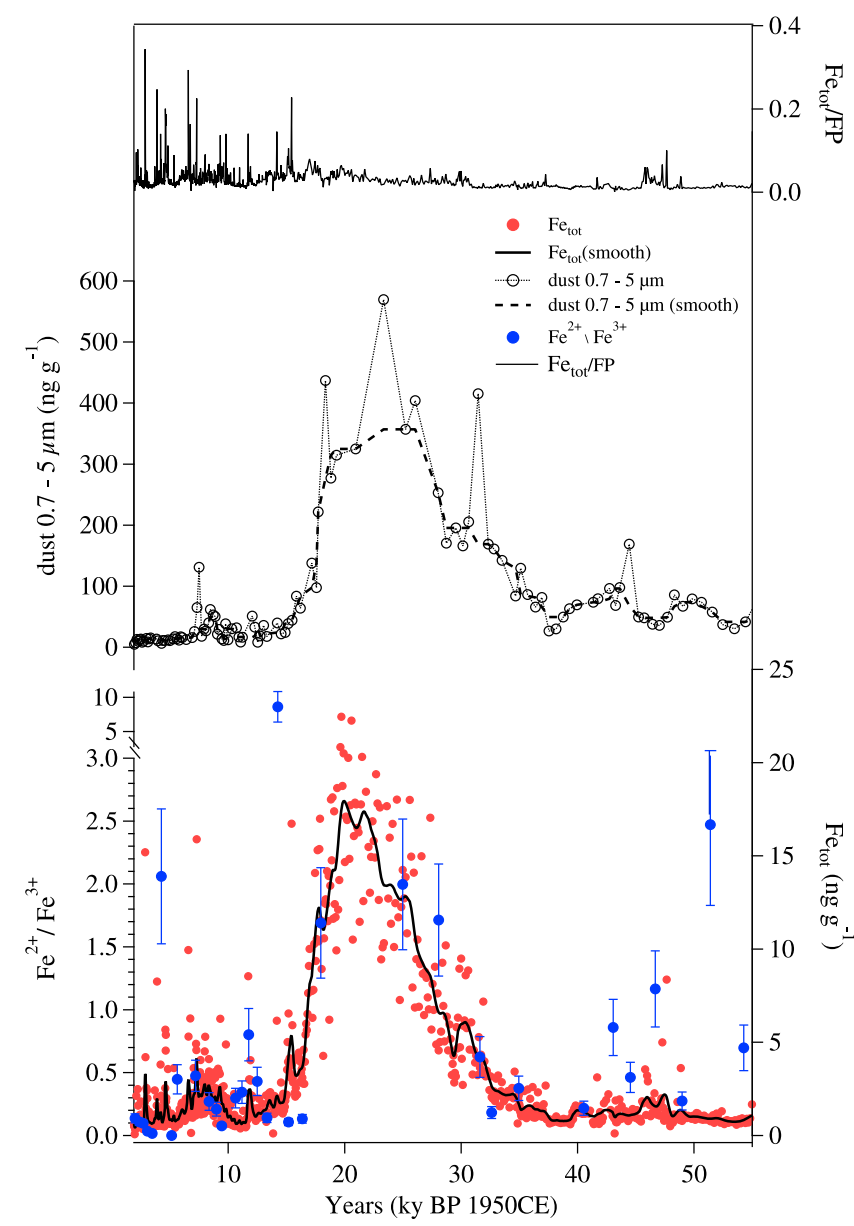

Figure 2. $\mathrm{Fe}^{2+} / \mathrm{Fe}^{3+}$ mass ratios (blue circles) compared to dissolvable iron concentrations (red circles; this work) and FD $(0.7-5 \mu \mathrm{m})$ concentrations (FP; empty circles) [Delmonte et al., 2010]. The thin black line represents the ratio between dissolvable iron and FD $(0.7-5 \mu \mathrm{m})$ concentrations. 
results from the production of $\mathrm{Fe}^{2+}$ by photoreduction of $\mathrm{Fe}^{3}$ ${ }^{+}$during atmospheric transport of FD.

[11] Our findings provide a link between FD particles and the enhancement of Fe(II) species in dust, both of which can linked to enhanced Fe solubility. Baker and Jickells [2006] proposed that iron solubility of mineral dust is primarily controlled by the surface area to volume ratio of the particles. Trapp et al. [2010] confirmed the proposal by demonstrating that iron solubility increases as its size fraction decreases (from 10 to below $2.5 \mu \mathrm{m}$ ) and attributed this to the enhancement of Fe(II). This is consistent with our finding that $\mathrm{Fe}^{2+}$ is associated with increased FD deposition in Antarctica. The 1-2 week transport time for glacial FD deposited in Antarctica allows time for the production of $\mathrm{Fe}^{2+}$ by photoreduction during atmospheric transport and/or cloud processing, as proposed by Zhuang et al. [1992a]. The greater increase of $\mathrm{Fe}^{2+}$ compared to $\mathrm{Fe}^{3+}$ during the glacial suggests that iron is present in a more soluble form (Figures $3 \mathrm{a}$ and $3 \mathrm{~b}$ ).

[12] Although there is extensive evidence that iron solubility is enhanced in the fine particle fraction of mineral dust aerosol, we consider also the potential for post-depositional alteration of the $\mathrm{Fe}^{2+} / \mathrm{Fe}^{3+}$ ratio in surface snow. Three different post-depositional processes are proposed to potentially alter $\mathrm{Fe}^{2+} / \mathrm{Fe}^{3+}$ ratios in Antarctica: photochemical processes in ice as well as the effects of organic compounds and the $\mathrm{pH}$ of the ice. Kim et al. [2010] demonstrated the possibility for photochemical production of $\mathrm{Fe}$ (II) by solar irradiation in simulated glacier ice loaded with iron oxide particles. One can assume that photochemical $\mathrm{Fe}^{2+}$ production would be constant over glacial-interglacial climate cycles and can therefore consider that photochemically produced $\mathrm{Fe}^{2+}$ would lead to an elevated background concentration of $\mathrm{Fe}^{2+}$ in TD ice. As we observe that TD $\mathrm{Fe}^{2+}$ concentrations are sometimes $<0.1 \mathrm{ng} \mathrm{g}^{-1}$, we consider photochemical production of $\mathrm{Fe}^{2+}$ to be insignificant compared to the glacial-interglacial variability observed in the record.

[13] Aside from $\mathrm{Fe}^{2+}$ production, we also consider the stability of $\mathrm{Fe}^{2+}$ in the presence of organic ligands and $\mathrm{pH}$ changes. Although $\mathrm{pH}$ [Millero, 1995] and organic complexation [Boye et al., 2001] are important factors controlling $\mathrm{Fe}$ solubility in seawater, much lower concentrations of organic

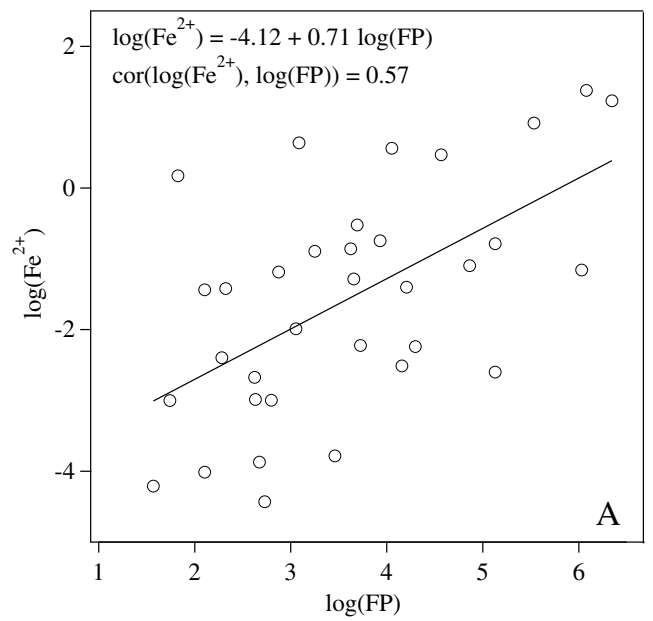

carbon and hence ligands are observed in Antarctic ice [Antony et al., 2011; Federer et al., 2008]. We must also consider the possibility for $\mathrm{Fe}$ (II) to be reoxidized to $\mathrm{Fe}$ (III) after deposition in the ice matrix. Fe(II) stability is $\mathrm{pH}$ dependent [Bruland, 2001], where low pH tends to stabilize the $\mathrm{Fe}(\mathrm{II}) / \mathrm{Fe}$ (III) system. Mineral dust salts buffer Greenland ice core $\mathrm{pH}$ to values of 5.3 to 5.5 [Pasteris et al., 2011], although $\mathrm{pH}$ can decrease in the presence of volcanic acids. If $\mathrm{Fe}(\mathrm{II})$ is more stable at lower $\mathrm{pH}$ values, then our findings of enhanced $\mathrm{Fe}^{2+}$ during the dustier (and therefore of higher $\mathrm{pH})$ glacial are likely to be conservative estimates. The presence of $\mathrm{Fe}(\mathrm{II})$ in atmospheric dust particles [Schroth et al., 2009; Zhuang et al., 1992b] further suggests that this species is stable following photoproduction. On the basis of these considerations, we suggest that photochemical production of $\mathrm{Fe}$ (II) in Antarctic ice is minimal with respect to dust $\mathrm{Fe}$ input, $\mathrm{Fe}(\mathrm{II})$ is stable in Antarctic ice on glacial-interglacial time scales, and the somewhat higher $\mathrm{pH}$ of Antarctic glacial ice, relative to Holocene ice, may lead to an underestimation of the glacial enhancement of $\mathrm{Fe}^{2+}$.

[14] We observe three non-LGM instances of $\mathrm{Fe}^{2+}$ enrichment in TD ice, one of which may be attributable to volcanism. The three greatest $\mathrm{Fe}^{2+} / \mathrm{Fe}^{3+}$ ratios reported here occurred at 4, 14, and $51 \mathrm{kyr} \mathrm{BP}$, with respective $\mathrm{Fe}^{2+} / \mathrm{Fe}^{3+}$ ratios of 2.1, 8.6, and 2.4 (Figure 2). Each of these abrupt changes was due to increased $\mathrm{Fe}^{2+}$ concentrations rather than lowered $\mathrm{Fe}^{3+}$ concentrations. The sample with both the greatest Holocene $\mathrm{Fe}^{2+}$ concentration and the highest observed $\mathrm{Fe}^{2+} / \mathrm{Fe}^{3+}$ ratio dates to $14 \mathrm{kyr} \mathrm{BP}$ and is contemporaneous with a doubling of sulfate concentrations indicative of volcanism [Severi et al., 2011]. Multiple studies [Ayris and Delmelle, 2012; Duggen et al., 2009] have indicated that dust plumes from volcanic eruptions contain $\mathrm{Fe}$ in a highly soluble and thus more bioavailable form but did not determine $\mathrm{Fe}$ species. Hence, we consider it likely that this sample contains $\mathrm{Fe}^{2+}$-enhanced dust of volcanic origin. The speciation of this sample may also be controlled by the ice $\mathrm{pH}$, which was lowered due to the presence of sulfate and potentially other volcanic acids. The influence of $\mathrm{pH}$ on Fe species stability and preferential molecular formation in ocean waters [Millero, 1995] and glacial ice [Spolaor et al., 2012] suggests the likelihood that volcanic acids promote the

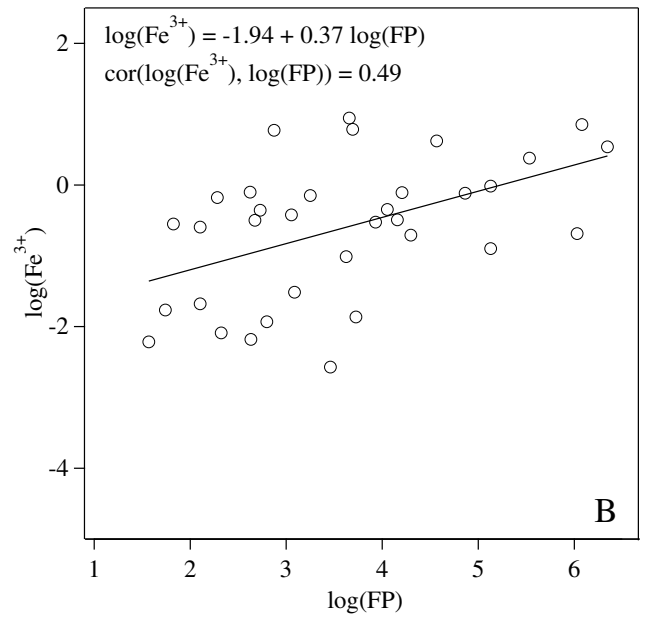

Figure 3. Correlation of Fe species with FD $(0.7-5 \mu \mathrm{m})$ concentrations $(\mathrm{FP})$. Scatterplots show correlations of log( $\left.\mathrm{Fe}^{2+}\right)$ versus $\log (\mathrm{FP})(\mathrm{a})$ and $\log \left(\mathrm{Fe}^{3+}\right)$ versus $\log (\mathrm{FP})(\mathrm{b})$. The slope of the regression line for $\log \left(\mathrm{Fe}^{2+}\right)$ is steeper than that for $\log \left(\mathrm{Fe}^{3+}\right)$, suggesting a stronger association of $\mathrm{Fe}^{2+}$ with $\mathrm{FD}(\mathrm{FP})$. 
formation and retention of $\mathrm{Fe}$ (II) in dust. The two other $\mathrm{Fe}^{2+} /$ $\mathrm{Fe}^{3+}$ peaks (4 and $51 \mathrm{kyr} \mathrm{BP}$ ) are not associated with high concentrations of sulfate or any other analytes and hence may simply result from natural variability in the $\mathrm{Fe}^{2+} / \mathrm{Fe}^{3+}$ ratios found in TD dust (Figure 2).

[15] We identified greater concentrations of $\mathrm{Fe}^{2+}$ during the glacial period compared to $\mathrm{Fe}^{3+}$, with particularly enhanced $\mathrm{Fe}^{2+} / \mathrm{Fe}^{3+}$ ratios during the LGM. Increased $\mathrm{Fe}^{2+}$ concentrations during the LGM suggest increased deposition of more soluble iron to the Southern Ocean. Consequently, the presence of more bioavailable iron during the LGM could have strengthened the effectiveness of the biological pump, particularly between 14 and $32 \mathrm{kyr}$ BP. The enhancement of $\mathrm{Fe}^{2+}$ in Antarctic ice during the glacial period is consistent with the photochemical formation of $\mathrm{Fe}^{2+}$ during long-range transport of FD (0.7-5 $\mu \mathrm{m}$ diameter). However, secondary post-depositional processes, the effect of aerosol $\mathrm{pH}$, and the presence of organic compounds should be further investigated. We find evidence that $\mathrm{Fe}$ in dust from volcanic plumes may be highly soluble due to $\mathrm{Fe}^{2+}$ enrichment, consistent with recent oceanographic Fe solubility studies [Ayris and Delmelle, 2012; Duggen et al., 2009]. Our results support the hypothesis [Baker and Jickells, 2006] that during glacial periods the iron present in long-range transported dust is in a more soluble and bioavailable form than that present during interglacial periods, with the ability to influence primary productivity in the Southern Ocean.

[16] Acknowledgments. This work was supported by the University of Siena and IDPA-CNR (Institute for the Dynamics of Environmental Processes, National Research Council). P.V. acknowledges the support of an EU Marie Curie IIF Fellowship (MIF1-CT-2006-039529, TDICOSO). We thank all our colleagues from the University of Venice Environmental Analytical Chemistry Laboratory for instrumental assistance, technical information, and manuscript corrections. Roberto Zuliani is especially thanked for technical assistance and development of the software used for the manifold control. The Talos Dome Ice Core Project (TALDICE), a joint European program, is funded by national contributions from Italy, France, Germany, Switzerland, and the United Kingdom. Primary logistical support was provided by PNRA at TD. This is TALDICE publication n. 32. This work was also supported by funding to the Past4Future project from the European Commission's 7th Framework Programme (grant 243908) and is Past4Future contribution n. 42.

\section{References}

Aguilar-Islas, A. M., J. Wu, R. Rember, A. M. Johansen, and L. M. Shank (2010), Dissolution of aerosol-derived iron in seawater: Leach solution chemistry, aerosol type, and colloidal iron fraction, Mar. Chem., 120(1-4), 25-33.

Antony, R., K. Mahalinganathan, M. Thamban, and S. Nair (2011), Organic Carbon in Antarctic Snow: Spatial Trends and Possible Sources, Environ. Sci. Technol., 45(23), 9944-9950.

Ayris, P., and P. Delmelle (2012), Volcanic and atmospheric controls on ash iron solubility: A review, Phys. Chem. Earth, Parts A/B/C, 45-46(0), 103-112, doi:10.1016/j.pce.2011.04.013.

Baker, A. R., and T. D. Jickells (2006), Mineral particle size as a control on aerosol iron solubility, Geophys. Res. Lett., 33(17), L17608, doi:10.1029/ 2006 GL026557.

Baker, A. R., and P. L. Croot (2010), Atmospheric and marine controls on aerosol iron solubility in seawater, Mar. Chem., 120(1-4), 4-13.

Barbante, C., G. Cozzi, G. Capodaglio, K. Van de Velde, C. P. Ferrari, C. F. Boutron, and P. Cescon (1999), Trace element determination in alpine snow and ice by double focusing inductively coupled plasma mass spectrometry with microconcentric nebulization, J. Anal. At. Spectrom., 14, 1433-1438.

Boye, M., C. M. G. van den Berg, J. T. M. de Jong, H. Leach, P. Croot, and H. J. W. de Baar (2001), Organic complexation of iron in the Southern Ocean, Deep Sea Res. Pt. I, 48(6), 1477-1497.

Bruland, K. W., and E. L. Rue (2001), The biogeochemistry of iron in seawater, in IUPAC Series on Analytical and Physical Chemistry of
Environmental Systems, edited by D. R. Turner, K. A. Hunter, pp. 255-290, Wiley, Chichester.

Chever, F., E. Bucciarelli, G. Sarthou, S. Speich, M. Arhan, P. Penven, and A. Tagliabue (2010), Physical speciation of iron in the Atlantic sector of the Southern Ocean along a transect from the subtropical domain to the Weddell Sea Gyre, J. Geophys. Res., 115(C10), C10059.

Coale, K. (1998), The Galapagos Iron Experiments: A tribute to John Martin - Preface, Deep-Sea Res. Pt. II, 45(6), 915-918.

de Baar, H. J. W., et al. (2005), Synthesis of iron fertilization experiments: From the iron age in the age of enlightenment, J. Geophys. Res.-Oceans, 110(C9), C09S16, doi:10.1029/2004JC002601.

Delmonte, B., et al. (2010), Aeolian dust in the Talos Dome ice core (East Antarctica, Pacific/Ross Sea sector): Victoria Land versus remote sources over the last two climate cycles, J Quat. Sci, 25(8), 1327-1337.

Duggen, S., N. Olgun, P. Croot, L. Hoffmann, H. Dietze, and C. Teschner (2009), The role of airborne volcanic ash for the surface ocean biogeochemical iron-cycle: a review, Biogeosci. Discuss., 6(4), 6441-6489.

Edwards, R., P. N. Sedwick, V. Morgan, and C. Boutron (2006), Iron in ice cores from Law Dome: A record of atmospheric iron deposition for maritime East Antarctica during the Holocene and Last Glacial Maximum, Geochem. Geophys. Geosyst., 7(12), Q12Q01, doi:10.1029/2006GC001307.

Federer, U., P. R. Kaufmann, M. A. Hutterli, S. Schupbach, and T. F. Stocker (2008), Continuous Flow Analysis of Total Organic Carbon in Polar Ice Cores, Environ. Sci. Technol., 42(21), 8039-8043.

Fischer, H., et al. (2010), The role of Southern Ocean processes in orbital and millennial CO2 variations - A synthesis, Quat. Sci. Rev., 29(1-2), 193-205.

Frezzotti, M., G. Bitelli, P. de Michelis, A. Deponti, A. Forieri, S. Gandolfi, V. Maggi, F. Mancini, F. Remy, and I. Tabacco (2004), Geophysical survey at Talos Dome, East Antarctica: the search for a new deep-drilling site, Ann. Glaciol., 39(1), 423-432.

Gabrielli, P., et al. (2005), Trace elements in Vostok Antarctic ice during the last four climatic cycles, Earth Planet Sc. Lett., 234(1-2), 249-259.

Gaspari, V., C. Barbante, G. Cozzi, P. Cescon, C. F. Boutron, P. Gabrielli, G. Capodaglio, C. Ferrari, J. R. Petit, and B. Delmonte (2006), Atmospheric iron fluxes over the last deglaciation: Climatic implications, Geophys. Res. Lett., 33, L03704, doi:10.1029/2005GL024352.

Jickells, T. D., et al. (2005), Global iron connections between desert dust, ocean biogeochemistry, and climate, Science, 308(5718), 67-71.

Joos, F., J. L. Sarmiento, and U. Siegenthaler (1991), Estimates of the effect of Southern Ocean iron fertilization on atmospheric CO2 concentrations, Nature, 349(6312), 772-775.

Kim, K., W. Choi, M. R. Hoffmann, H.-I. Yoon, and B.-K. Park (2010), Photoreductive Dissolution of Iron Oxides Trapped in Ice and Its Environmental Implications, Environ. Sci. Technol., 44(11), 4142-4148.

Martin, J. H., and S. E. Fitzwater (1988), Iron deficiency limits phytoplankton growth in the north-east Pacific subarctic, Nature, 331(6154), 341-343.

Millero, F. J. (1995), Thermodynamics of the Carbon-Dioxide System in the Oceans, Geochim. Cosmochim. Acta, 59(4), 661-677.

Pasteris, D. R., J. R. McConnell, and R. Edwards (2011), High-Resolution, Continuous Method for Measurement of Acidity in Ice Cores, Environ. Sci. Technol., 46(3), 1659-1666.

Raiswell, R., and D. E. Canfield (2012), The Iron Biogeochemical Cycle Past and Present, Geochemical Perspectives, 1(1), 1-220, doi:10.7185/ geochempersp.1.1.

Rue, E. L., and K. W. Bruland (1995), Complexation of iron(III) by natural organic ligands in the Central North Pacific as determined by a new competitive ligand equilibration/adsorptive cathodic stripping voltammetric method, Mar. Chem., 50(1, Äi4), 117-138.

Ruth, U., C. Barbante, M. Bigler, B. Delmonte, H. Fischer, P. Gabrielli, V. Gaspari, P. Kaufmann, F. Lambert, and V. Maggi (2008), Proxies and measurement techniques for mineral dust in Antarctic ice cores, Environ. Sci. Tech., 42(15), 5675-5681.

Schroth, A. W., J. Crusius, E. R. Sholkovitz, and B. C. Bostick (2009), Iron solubility driven by speciation in dust sources to the ocean, Nat. Geosci., 2(5), 337-340.

Severi, M., R. Udisti, S. Becagli, B. Stenni, and R. Traversi (2011), Volcanic synchronisation of the EPICA-DC and TALDICE ice cores for the last 42 kyr BP, Clim. Past Discuss., 7(5), 3719-3743.

Shaked, Y., A. B. Kustka, and F. M. M. Morel (2005), A general kinetic model for iron acquisition by eukaryotic phytoplankton, Limnol. Oceanogr., 50(3), 10.

Smetacek, V., et al. (2012), Deep carbon export from a Southern Ocean iron-fertilized diatom bloom, Nature, 487(7407), 313-319.

Spolaor, A., P. Vallelonga, J. Gabrieli, G. Cozzi, C. Boutron, and C. Barbante (2012), Determination of Fe2+ and Fe3+ species by FIA-CRC-ICP-MS in Antarctic ice samples, J Anal Atom Spectrom 27, 310-317.

Stenni, B., et al. (2011), Expression of the bipolar see-saw in Antarctic climate records during the last deglaciation, Nat. Geosci., 4(1), 46-49. 


\section{SPOLAOR ET AL.: IRON SPECIATION IN ICE CORES}

Sunda, W. G. (2010), Iron and the Carbon Pump, Science, 327(5966), 654-655. Trapp, J. M., F. J. Millero, and J. M. Prospero (2010), Trends in the solubility of iron in dust-dominated aerosols in the equatorial Atlantic trade winds: Importance of iron speciation and sources, Geochem. Geophys. Geosyst., 11(3), Q03014, doi:10.1029/2009GC002651.

Vallelonga, P., C. Barbante, G. Cozzi, J. Gabrieli, S. Schüpbach, A. Spolaor, and C. Turetta (2013), Iron fluxes to Talos Dome, Antarctica, over the past 200 kyr, Clim. Past, 9(2), 597-604, doi:10.5194/cp-9-597-2013.

Wolff, E., C. Barbante, S. Becagli, M. Bigler, C. Boutron, E. Castellano, M. De Angelis, U. Federer, H. Fischer, and F. Fundel (2010), Changes in environment over the last 800,000 years from chemical analysis of the EPICA Dome C ice core, Quat. Sci. Rev., 29(1-2), 285-295.

Wolff, E., et al. (2006), Southern Ocean sea-ice extent, productivity and iron flux over the past eight glacial cycles, Nature, 440(7083), 491-496.

Zhuang, G., Z. Yi, R. A. Duce, and P. R. Brown (1992a), Chemistry of iron in marine aerosols, Global Biogeochem. Cycles, 6(2), 161-173, doi:10.1029/ 92GB00756.

Zhuang, G., Z. Yi, R. A. Duce, and P. R. Brown (1992b), Link between iron and sulphur cycles suggested by detection of $\mathrm{Fe}(\mathrm{II})$ in remote marine aerosols, Nature, 355(6360), 537-539. 